\title{
EFFECTS OF MERCURY ON REPRODUCTION, AVOIDANCE, AND HEAT SHOCK PROTEIN GENE EXPRESSION OF THE SOIL SPRINGTAIL FOLSOMIA CANDIDA
}

\author{
Yu-Rong Liu, $\dagger \ddagger$ Yuan-Ming Zheng, $†$ Li-Mei Zhang, $†$ Yun-Xia Luan, $\S$ and Ji-Zheng He* $†$ \\ $\dagger$ State Key Laboratory of Urban and Regional Ecology, Research Center for Eco-Environmental Sciences, Chinese Academy of Sciences, \\ Beijing 100085, China \\ $\ddagger$ Graduate University, Chinese Academy of Sciences, Beijing 100049, China \\ $\S$ Institute of Plant Physiology and Ecology, Chinese Academy of Sciences, Shanghai 200032, China
}

(Submitted 2 August 2009; Returned for Revision 31 August 2009; Accepted 21 September 2009)

\begin{abstract}
Based on the Cambisols of Beijing (used as agricultural soils), toxicity tests were conducted to investigate the effects of mercury $(\mathrm{Hg})$ on reproduction and avoidance of Folsomia candida (Hexapoda: Collembola), as well as the transcriptional responses of the hsp70 gene, under different $\mathrm{Hg}$ concentrations and at different exposure times. Results showed that the hsp70 gene of the springtail was the most sensitive parameter to soil $\mathrm{Hg}$ stress, with a half-maximal effective concentration (EC50) of $0.42 \mathrm{mg} / \mathrm{kg}$. The EC50 values based on reproduction and avoidance tests were 9.29 and $3.88 \mathrm{mg} / \mathrm{kg}$, respectively. The expression level of the hsp70 gene was significantly up-regulated when soil $\mathrm{Hg}$ concentration was over $0.25 \mathrm{mg} / \mathrm{kg}$ (lowest-observed-effect concentration [LOEC]). In addition, responses of this gene expression were strongly induced after $48 \mathrm{~h}$ exposure under $1 \mathrm{mg} / \mathrm{kg}$ soil $\mathrm{Hg}$, which probably was due to the fast and sensitive response of the gene transcription to $\mathrm{Hg}$ stress. Thus, the results suggested that the responses of the hsp70 gene and individual-level effects (reproduction and avoidance) could be integrated to provide helpful information for environmental monitoring and assessment of contaminated soils. Environ. Toxicol. Chem. 2010;29:654-659. (C) 2009 SETAC
\end{abstract}

Keywords_Folsomia candida Avoidance hsp70 gene Mercury Soil risk assessment

\section{INTRODUCTION}

Soil mercury $(\mathrm{Hg})$ pollution is a worldwide problem that could threaten the sustainability of essential soil functions and the safety of human health [1], and the evaluation of $\mathrm{Hg}$ toxicity and bioavailability has been of widespread concern $[2,3]$. Biological approaches are useful for investigating the effects of bioavailable pollutants on organisms and their interaction. The springtail Folsomia candida is one of the important model organisms, which has been used in ecotoxicological tests of pollutants [4]. Some endpoints, such as survival, growth, and reproduction, have been commonly used in contaminated soil diagnosis and risk assessments because of sensitive responses of $F$. candida to environmental pollution [5-11]. In addition, the avoidance of $F$. candida in response to heavy metal stress has been used to evaluate the toxicity of pollutants to $F$. candida [12-14], although little information is available regarding the avoidance response of $F$. candida to soil $\mathrm{Hg}$ stress.

Many toxicological bioassays have shown that both molecular and whole-individual methods play important roles in determining biological responses to stressors [15]. Thus, some functional gene expressions of springtails following contaminated soil exposure have been used as endpoints, for example, the variation of metallothionein gene expression in the springtails Orchesella cincta exposed to Cd [16,17]. With the development of genomic techniques, springtail ecotoxicoge-

* To whom correspondence may be addressed (jzhe@rcees.ac.cn).

Published online 9 November 2009 in Wiley InterScience (www.interscience.wiley.com). nomic studies have been used to investigate the variation of all gene expressions under different stress, which further improved our knowledge of the mechanisms responsive to stress in $F$. candida $[18,19]$. However, the applications of gene expression as a biomarker in environmental diagnosis or assessment are still very limited.

Biomarkers are used in early environmental diagnostics as predictive molecular-genetic, biochemical, cellular, or physiological responses to sublethal toxicant stress [20,21]. The heat shock protein (hsp) gene, despite debates and limitations, has been widely used in several organisms as a potential biomarker for monitoring environmental pollution [22-24]. The stressinducible hsp70 is the most highly conserved and largest gene in all hsp families, which is caused by a more pronounced need for chaperones in order to maintain optimal cell function and homeostasis $[25,26]$. This inducible protein-coding gene can be expressed at extremely low levels of pollutant under normal conditions, and its transcription and translation will increase rapidly in response to various stressors [27]. Studies of the soil invertebrates Lumbricus terrestris and Eisenia fetida showed that the hsp70 gene was up-regulated after metal exposure $[28,29]$. Recently, it was also reported that there was a strong correlation between hsp70 expression in the springtail $O$. cincta and its thermal resistance [30]. The expression of the hsp70 gene in $\mathrm{F}$. candida exposed to $\mathrm{Hg}$ together with cold or heat stress was also studied in aquatic environments [31,32]. However, little information was available on the effect of $\mathrm{Hg}$ pollution on the hsp70 gene expression in the soil environment.

The aim of the present study was to compare the sensitivity of different endpoints in $\mathrm{F}$. candida to soil $\mathrm{Hg}$ stress from individual to molecular levels. The effects of $\mathrm{Hg}$ on reproduc- 
tion, avoidance, and hsp70 biomarker were measured with exposure to different $\mathrm{Hg}$ concentrations. Results based on these tests could be useful for the early and fast diagnosis of soil contamination and environmental risk assessment.

\section{MATERIALS AND METHODS}

Test soil and chemical analyses

The soil used in the study was collected from an agricultural field in the suburbs of Beijing, China. It was atypical fluvoaquic sandy loam soil (Cambisol, 9.0\% clay, 21.8\% silt, $69.2 \%$ sand). More information on soil characteristics is given in Table 1, in which a slightly high $\mathrm{Zn}$ concentration was considered to be of little impact on the test according to pre-experiments. Soil samples were air dried and ground to a size finer than $2 \mathrm{~mm}$ for incubation experiments and $0.149 \mathrm{~mm}$ for chemical analyses. Soil $\mathrm{pH}$ was determined at a soil:water ratio of 1:2.5, and soil organic matter was determined by the $\mathrm{K}_{2} \mathrm{Cr}_{2} \mathrm{O}_{7}$ oxidation method [33]. For general element analysis, soil was digested with $\mathrm{HNO}_{3}$ and $\mathrm{H}_{2} \mathrm{O}_{2}$, and for $\mathrm{Hg}$ analysis the soil was digested with $\mathrm{HNO}_{3}+\mathrm{HCl}(10 \mathrm{ml}, 1: 1 \mathrm{v} / \mathrm{v})$ [34]. Manganese, $\mathrm{Fe}, \mathrm{Cu}, \mathrm{Zn}$, and $\mathrm{Cr}$ were analyzed by inductively coupled plasma optical emission spectroscopy (PerkinElmer), and $\mathrm{Hg}$ was analyzed by atomic fluorescence spectroscopy (AFS; AFS-2202E Haiguang Analytical Instrument). Two standard reference soils, GBW07401 (GSS-1) and GBW-07405 (GSS-5), obtained from the Center for National Standard Reference Materials of China, were included in the analytical process for quality assurance/ quality control.

Test $\mathrm{F}$. candida

The strain of $F$. candida was provided by the Institute of Plant Physiology and Ecology, Chinese Academy of Sciences. The individuals were cultured at $20 \pm 1{ }^{\circ} \mathrm{C}$ with a $12: 12-\mathrm{h}$ light:dark cycle. The springtails were kept in Petri dishes containing a mixture of water-saturated charcoal and plaster of Paris (1:8) and fed with granulated baker's dry yeast. Water was added once per week to maintain humidity. Adult animals were transferred to fresh containers, in which the springtails oviposited for $48 \mathrm{~h}$, and then were removed. After 7 to $10 \mathrm{~d}$, the eggs hatched and the juveniles were bred synchronously to ensure that all individuals were of approximately the same age at the beginning of the experiments.

\section{General experimental design}

Effects of $\mathrm{Hg}$ on reproduction. Chronic toxicity tests with $F$. candida were conducted following the International Organization for Standardization 11267 method [35]. The unpolluted soil was spiked with $\mathrm{Hg}$, i.e., $2,5,10$, or $20 \mathrm{mg} / \mathrm{kg}$, by adding a solution of $\mathrm{HgCl}_{2}$. The solutions were mixed thoroughly with the soil to give a moisture content of $55 \%$ of the water-holding capacity. One week after spiking, 10 springtails (10-12 d old) were exposed in each experimental vessel containing $30 \mathrm{~g}$ of spiked soil or control soil. Granulated dry yeast was spread every 2 weeks on the soil surface as food. Five replicates were used for each concentration. The test vessels were kept at $20 \pm 1{ }^{\circ} \mathrm{C}$ with a 12:12-h light:dark cycle for $28 \mathrm{~d}$. At the end of exposure, juveniles and adults were counted after extraction by flooding with water.

Avoidance tests. Unpolluted soil was spiked with $\mathrm{Hg}$, i.e., 0 , $0.5,1,2,5,10$, or $30 \mathrm{mg} / \mathrm{kg}$. Cylindrical plastic containers $(7 \mathrm{~cm}$ in diameter and $6 \mathrm{~cm}$ in depth), divided into two sections by a cardboard divider inserted transversally, were used in the avoidance tests with $F$. candida. The two sections of the test container were filled with $30 \mathrm{~g}$ of control and spiked soil (dry $w t$, respectively [12]. Then, the divider was removed and 20 springtails were placed carefully onto the midline of each test container. Each treatment consisted of five replicates. The test containers were kept at $20 \pm 1^{\circ} \mathrm{C}$ with a 12:12-h light:dark cycle for $48 \mathrm{~h}$. At the end of exposure, the divider was reinserted. Then, the contents of two sections of the container were emptied separately into small vessels and flooded with water. A dual control test was also performed (both sections filled with soil with the same $\mathrm{Hg}$ level).

Transcriptional responses of hsp70 gene to $\mathrm{Hg}$ concentration. Based on results of the reproduction test, the soil was spiked with a maximum $\mathrm{Hg}$ concentration of $8 \mathrm{mg} / \mathrm{kg}$ (lower than the EC50 concentration of $9.29 \mathrm{mg} / \mathrm{kg}$ ), i.e., 0.25 , $0.5,1,2,4$, and $8 \mathrm{mg} / \mathrm{kg}$. Four replicates were designed for both control and spiked soils. The exposure time was $4 \mathrm{~d}$. To make the springtails eat food that originally existed in the soil, no other food was added during the experiments. Thirty springtails were placed carefully into each test container, and four replicates were designed for every treatment. Other general conditions during the exposure were the same as in the reproduction assay. When the exposure was ended, springtails were extracted from the spiked soil and carefully moved to Petri dishes containing a mixture of charcoal and plaster of Paris to remove surplus water. They were then put in sterile tubes, in which they were snap frozen in liquid nitrogen and kept at $-80^{\circ} \mathrm{C}$ for RNA extraction. The whole harvesting procedure took approximately 4 min per sample.

Transcriptional responses of hsp70 gene to exposure time. The soil was spiked with a final concentration of $1 \mathrm{mg}$ $\mathrm{Hg} / \mathrm{kg}$ soil, which was designed based on results of pre-experiments. The tested number of individuals and all other procedures were the same as described above. After exposure, springtails were collected after different exposure times, i.e., $6,12,24,48,96$, and $240 \mathrm{~h}$.

\section{Real-time quantitative polymerase chain reaction}

$R N A$ extraction and reverse transcription. All expression analyses were conducted on total RNA extracted from exposed springtails, using Trizol reagent (Molecular Research Center,

Table 1. Selected basic chemical characteristics of the tested soil

Total metal concentration in the soil $(\mathrm{mg} / \mathrm{kg})$

\begin{tabular}{cccccccccc}
\cline { 3 - 3 }$\left(\mathrm{H}_{2} \mathrm{O}\right)$ & $\mathrm{OM}^{\mathrm{a}}(\%)$ & Total N $(\mathrm{g} / \mathrm{kg})$ & Available $\mathrm{P}(\mathrm{mg} / \mathrm{kg})$ & $\mathrm{Mn}$ & $\mathrm{Fe}$ & $\mathrm{Cu}$ & $\mathrm{Zn}$ & $\mathrm{Cr}$ & $\mathrm{Hg}$ \\
\hline 7.14 & 2.05 & 0.83 & 9.51 & 458 & 24525 & 2.36 & 89.23 & 4.53 & 0.05 \\
\hline
\end{tabular}

${ }^{\text {a }}$ Organic matter. 
Table 2. Polymerase chain reaction primer pairs

\begin{tabular}{|c|c|c|c|c|}
\hline Gene & Amplicon length (bp) & Code & Sequence $5^{\prime}-3^{\prime}$ & Reference \\
\hline $28 \mathrm{~S}$ & 534 & $28 \mathrm{~S}-\mathrm{R}$ & CCCACAGCGCCAGTTCTGCTTACC & [43] \\
\hline$\beta$-Actin & 111 & ACT-1R & GCGACGTTGATATCCGAAAG & This study \\
\hline \multirow[t]{2}{*}{ hsp70 } & \multirow[t]{2}{*}{243} & $\mathrm{H} 7-1 \mathrm{~F}$ & GCGACGTTGATATCCGAAAG & \multirow[t]{2}{*}{ This study } \\
\hline & & H7-1R & GCGACGTTGATATCCGAAAG & \\
\hline
\end{tabular}

Invitrogen) according to the manufacturer's instructions. RNA purity and integrity were checked by ensuring that the absorbance ratio (A260/280) was between 1.8 and 2.0 and by agarose gel electrophoresis (2\%). For cDNA synthesis, $2 \mu$ l total RNA ( $350 \mathrm{ng} / \mu \mathrm{l})$ was reverse transcribed. The first-strand cDNA was synthesized using Moloney murine leukemia virus $(\mathrm{MMLV})$ reverse transcriptase (Promega) and oligod(T) 15 according to the manufacturer's instructions.

Cloning and sequencing. A $28 \mathrm{~S}$ gene polymerase chain reaction (PCR) was conducted to check initially the results of reverse transcription. The $\beta$-actin gene was chosen as an internal control for hsp70 gene quantification [17]. Two pairs of primers were developed according to the nucleotide database from GenBank, as shown in Table 2. Polymerase chain reactions were done with Taq polymerase (Takara), following 35 cycles of $20 \mathrm{~s}$ at $94^{\circ} \mathrm{C}, 30 \mathrm{~s}$ at $58^{\circ} \mathrm{C}$, and $30 \mathrm{~s}$ at $72^{\circ} \mathrm{C}$. The PCR products were cloned into the pGEM-T Easy Vector (Promega). The recombinant clones were purified using a MiniBEST Plasmid Purification Kit (Takara). Two or three clones for each gene were sequenced, and the sequence analysis was performed by comparison with the GenBank database.

Two standard curves for real-time PCR. The two plasmid DNA concentrations were determined on a Nanodrop ${ }^{\circledR}$ ND1000 spectrophotometer (NanoDrop Technologies), and the copy numbers of hsp70 and $\beta$-actin gene were calculated directly from the concentration of extracted plasmid DNA. Tenfold serial dilutions of a known copy number of plasmid DNA were subjected to real-time PCR assay in triplicate to generate standard curves for quantifying the two genes of interest.

Relative quantification of gene expression levels. Real-time PCR assays were performed on an iCycler iQ 5 thermocycler (Bio-Rad) for both target and internal control genes. Real-time PCRs (qPCR) were prepared for 25- $\mu$ l mixtures: $2 \mu$ cDNA, $0.5 \mu \mathrm{M}$ each $\beta$-actin or hsp70 gene primer, $9.5 \mu$ l diethypyrocarbonate (DEPC) water, and $12.5 \mu \mathrm{l} \mathrm{SYBR}{ }^{\circledR}$ Premix Ex $\mathrm{Taq}^{\mathrm{TM}}$ (TaKaRa). The following PCR conditions of the two genes were used: denaturation step $\left(95^{\circ} \mathrm{C}, 1 \mathrm{~min}\right)$, amplification and quantification step repeated 40 times $\left(95^{\circ} \mathrm{C}\right.$ for $20 \mathrm{~s}, 57^{\circ} \mathrm{C}$ for $30 \mathrm{~s}, 72^{\circ} \mathrm{C}$ for $\left.10 \mathrm{~s}\right)$, melting curve step $\left(55-95^{\circ} \mathrm{C}\right.$ with a heat rate of $0.5^{\circ} \mathrm{C}$ per $\mathrm{s}$ and continuous florescence measurement), and a cooling step at $40^{\circ} \mathrm{C}$. Analyses of melting curves allowed optimization of annealing temperatures for amplificationproducts. Quantifications of both hsp70 and $\beta$-actin genes were conducted on the same plate to reduce systematic error. For each mRNA, the absence of contamination (genomic DNA) was checked using a no-RT control with $\beta$-actin and 28S primer.

\section{Statistical analyses}

The data from the three toxicity tests were fitted to suitable regression models [36,37]: reproduction results with a hormesis model $\left(r^{2}=0.99, p<0.01\right)$, avoidance results with a logistic model $\left(r^{2}=0.99, p<0.01\right)$, and hsp70 response with a logistic model $\left(r^{2}=0.94, p<0.05\right)$. The EC50 values were calculated in the statistical package SigmaPlot 10.0.

No-observed-effect concentrations (NOEC) and lowobserved-effect concentrations (LOEC) were determined by comparing reproduction rates, avoidance percentages, and relative expression levels of the hsp70 gene with corresponding control using Mann-Whitney $U$ tests. Statistical significance was considered at $p<0.05$. Gene expression was calculated by quantification of the hsp70 gene compared with quantification of the $\beta$-actin gene, which were measured by the iCycler iQ 5, and then the control treatment was normalized as a value of 1 . One-way analysis of variance was used to assess differences between treatments, and all results are presented as means with standard errors. Statistical significance was assessed by the software SPSS ${ }^{\circledR} 11.5$.

\section{RESULTS}

\section{Reproduction and mortality}

The over $80 \%$ survival rates and more than 100 juveniles produced in controls proved that the test was valid. The effects of soil $\mathrm{Hg}$ on the reproduction of springtails are shown in Figure 1. There was a decreasing trend when soil $\mathrm{Hg}$ concentration was higher than $5 \mathrm{mg} / \mathrm{kg}$. The EC50 value based on

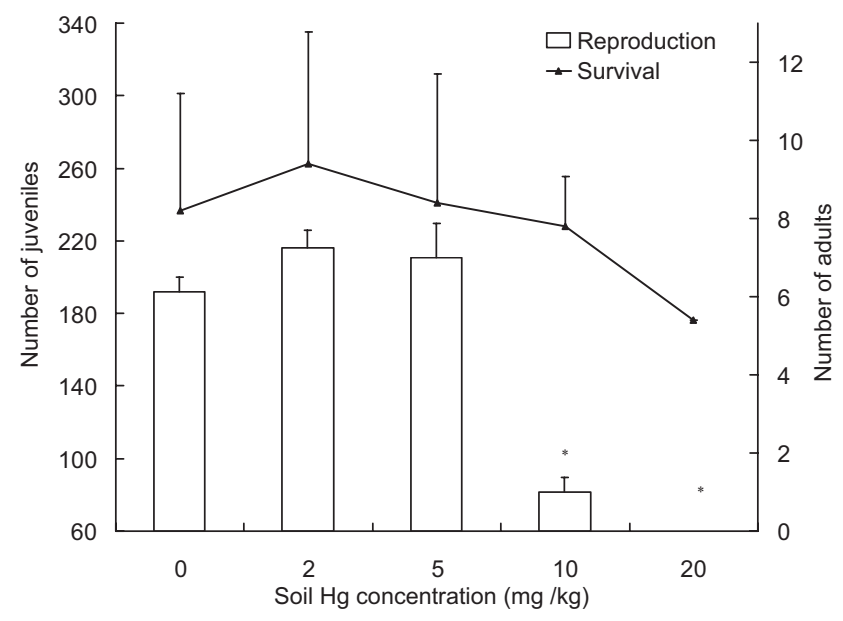

Fig. 1. Reproduction (bars; left $y$ axis) and adult survival (curve; right $y$ axis) of the springtail Folsomia candida exposed for $28 \mathrm{~d}$ to $\mathrm{Hg}$-contaminated soils at different $\mathrm{Hg}$ concentrations. Error bars indicate standard deviation (SD). ${ }^{*}$ Significantly different from control $(p<0.05)$. 
Table 3. Effect concentration with 50\% effect (EC50), no-observed-effect concentration (NOEC) and lowest-observed-effect concentration (LOEC) per $\mathrm{mg} \mathrm{Hg} / \mathrm{kg}$ soil for Folsomia candida after exposure to $\mathrm{Hg}$-spiked soil

\begin{tabular}{lccc}
\hline & Reproduction & Avoidance & hsp70 Gene expression \\
\hline EC50 & 9.29 & 3.88 & 0.42 \\
NOEC & 5 & 2 & - \\
LOEC & 10 & 5 & 0.25 \\
\hline
\end{tabular}

reproduction was $9.29 \mathrm{mg} / \mathrm{kg}(p<0.05$; shown in Table 3$)$. A significant decrease in the reproduction rate was found at the concentration of $10 \mathrm{mg} / \mathrm{kg}$ compared with the control soil, and no juvenile was found at the concentration of $20 \mathrm{mg} / \mathrm{kg}$. No significant effect of soil $\mathrm{Hg}$ on the mortality of $F$. candida was observed, although mortality was increased at the highest $\mathrm{Hg}$ concentration.

\section{Avoidance tests}

An average survival rate of $99 \pm 1 \%$ was determined for all tested samples. Dual-control tests showed a random distribution of individuals in both sections of the test containers (data not presented) in all treatments. Testing soils with different $\mathrm{Hg}$ concentrations showed that there were significantly lower percentages of individuals in sections with soil polluted with more than $2 \mathrm{mg} / \mathrm{kg}$ compared with control soil (Fig. 2). An increasing trend of avoidance was found with ascending $\mathrm{Hg}$ concentration in the soil above $1 \mathrm{mg} / \mathrm{kg}$.

\section{Cloning and sequencing}

Gene sequencing showed that the two partial fragments were both the genes of interest. Each sequence was identified using BLAST in the National Centre for Biotechnology Information. Sequence data were submitted to GenBank (accession Nos. FJ476077 for the hsp70 gene and FJ476078 for the $\beta$-actin gene).

\section{Transcriptional responses of the hsp70 gene}

Different soil $\mathrm{Hg}$ concentrations. Mercury exposure had significant effects on relative expression of the hsp70 gene

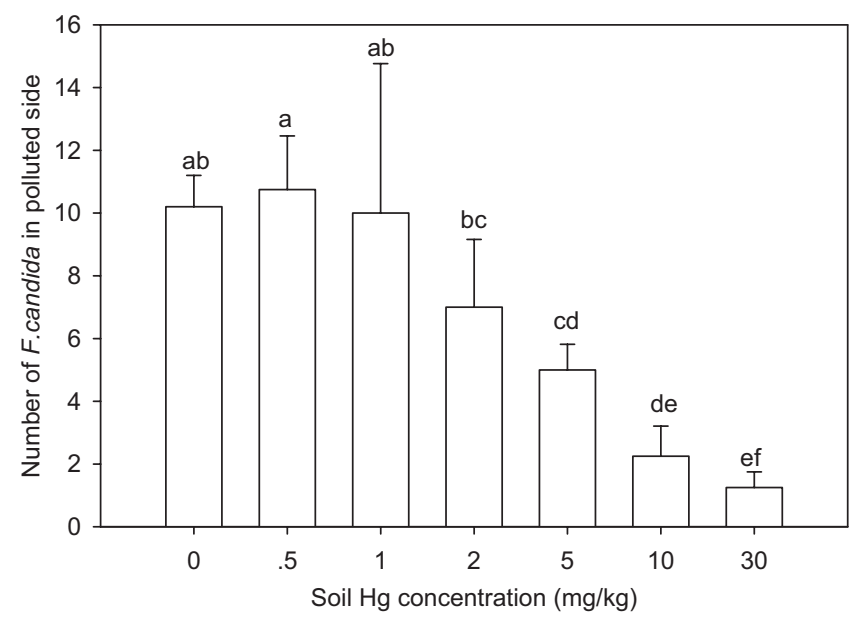

Fig. 2. Avoidance behavior of Folsomia candida in tests with soils spiked at different $\mathrm{Hg}$ concentrations. Values are numbers of individuals (mean $\pm \mathrm{SD}$ ) in the control side of test containers. Columns within each concentration not sharing the same lowercase letter are significantly different $(p<0.05)$.

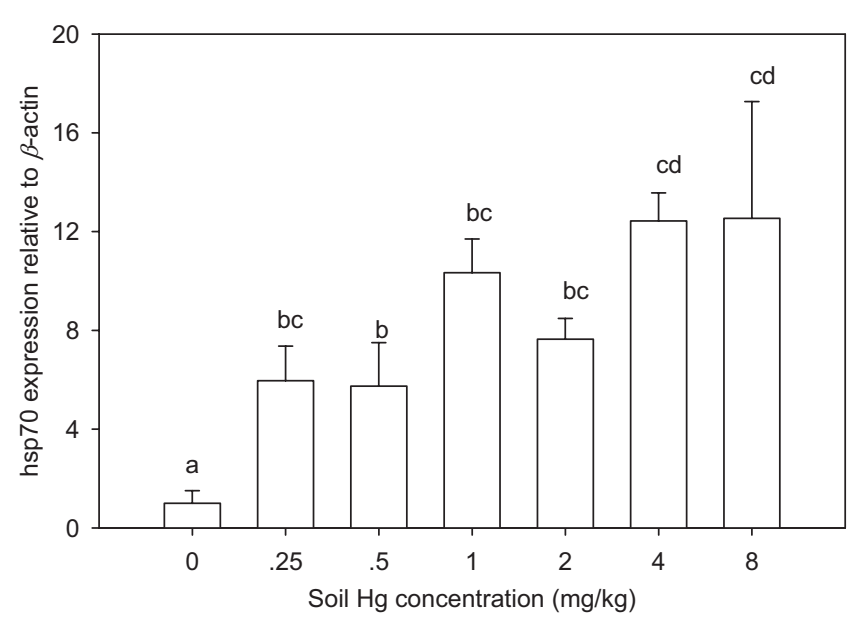

Fig. 3. Expression of the hsp70 gene in Folsomia candida exposed to a control and to increasing test concentrations of soil $\mathrm{Hg}$. Bars are mean of four relative expressions \pm standard error (SE). Columns within each concentration not sharing the same lowercase letter are significantly different $(p<0.05)$.

compared with the control (Fig. 3). A significantly higher expression level of the hsp70 gene was found when the $\mathrm{Hg}$ concentration was greater than or equal to $0.25 \mathrm{mg} / \mathrm{kg}$ $(p<0.05)$. There was an increasing trend of expression with the rise in soil $\mathrm{Hg}$ concentration, and the highest expression level of the hsp70 gene was observed at $8 \mathrm{mg} \mathrm{Hg} / \mathrm{kg}$ soil.

Exposure time following soil $\mathrm{Hg}$ stress. No significantly different expression levels of the hsp70 gene were observed from 0 to $24 \mathrm{~h}$ exposure to soil $\mathrm{Hg}$ (Fig. 4). Afterward, the hsp70 gene expression increased significantly up to about three times that of the control $(p<0.05)$. Then, there was some fluctuation in the expression levels, which remained higher than the control. Overall relative expression levels of 2-d, 4-d, and 10-d exposure times were significantly higher than the gene expression levels determined earlier.

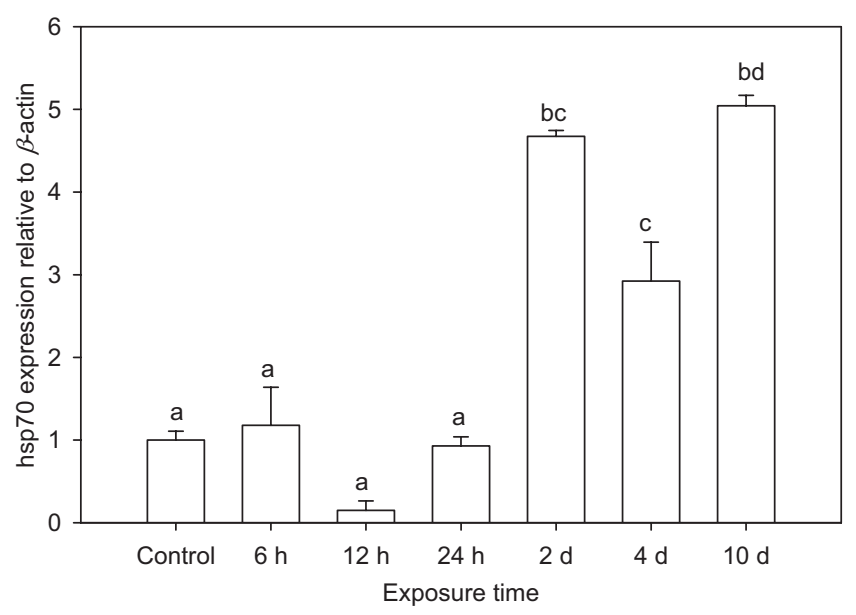

Fig. 4. Expression of the hsp70 gene in Folsomia candida at different exposure times at a concentration of $1 \mathrm{mg} \mathrm{Hg} / \mathrm{kg}$ soil. Bars are the mean of four relative expressions $\pm \mathrm{SE}$. Columns within each time not sharing the same letter are significantly different $(p<0.05)$. 


\section{Comparison of toxicity values in the different endpoints}

Toxicity parameters based on the three endpoints are shown in Table 3. The EC50 and LOEC values based on reproduction, avoidance, and hsp70 gene expression decreased in that order. The lowest EC50 value was $0.42 \mathrm{mg} / \mathrm{kg}$ calculated according to the hsp70 biomarker. In addition, the LOEC based on the reproduction test was 40-fold higher than that based on gene expression. The NOEC values for reproduction and avoidance were 5 and $2 \mathrm{mg} / \mathrm{kg}$, respectively.

\section{DISCUSSION}

In present study, tests of chronic toxicity revealed that there were significant effects of soil $\mathrm{Hg}$ on the reproduction of F. candida at concentrations above $10 \mathrm{mg} / \mathrm{kg}$. The corresponding EC50 value was higher than that measured by Lock and Janssen [3], which could be attributed to the difference between the clones used in the various laboratories [14,38]. It might also be related to the natural variability of $F$. candida populations and the difference in $\mathrm{Hg}$ bioavailability depending on soil characteristics. Therefore, it is necessary to use synchronous clones and the same soil when comparing the toxicity of different chemicals. There was no significant variation of mortality among any of the treatments. This lack of sensitivity of mortality was also observed in ecotoxicological tests of cobalt with the same species [39].

The springtail $F$. candida exhibited an increasing tendency to avoid soils with ascending $\mathrm{Hg}$ concentrations, which agreed with studies indicating the avoidance of several chemicals by earthworms and isopods [40]. The avoidance test of $F$. candida to soil $\mathrm{Hg}$ was more sensitive than the reproduction test. Basically, from this point of view, avoidance in this species is suitable as a screening tool in ecological risk assessment for contaminated land, as suggested in other studies [12,14,41].

The hsp70 gene expression in F. candida was measured as an endpoint in this study. Not only was total hsp70 gene relative expression significantly higher at all test concentrations compared with the control but the hsp70 gene could be induced at a very low soil $\mathrm{Hg}$ concentration $(0.25 \mathrm{mg} / \mathrm{kg}$ in this experiment), with which no response was produced in reproduction and avoidance tests. This could be explained by the fact that the up-regulation of the gene should be produced before any physiological variation in the organism could be observed. Therefore, the hsp70 could be a promising biomarker for soil $\mathrm{Hg}$ pollution and suitable for early diagnosis of contamination. The relative expression levels of the hsp70 gene seemed to increase with soil $\mathrm{Hg}$ concentration, which also fit the doseresponse model. On the other hand, approximately four- to sixfold higher gene expression levels were observed after 48-h exposure compared with that in the control or the treatment with 24-h exposure. This finding suggested that the hsp70 protein coding was strongly induced in a short time. However, this trend leveled off with the increase in the exposure time, which could be a result of physiological acclimation that allows the organisms to be tolerant to pollution [42] or because enough hsp70 protein had been produced. Meanwhile, it has been suggested that the up-regulation of some genes was involved in the tolerance to prolonged exposure to stressors [20]. In fact, variations at the individual level following $\mathrm{Hg}$ exposure depend, at least in part, on those genes responsible for the corresponding adaptive mechanisms being regulated or differentially expressed.

The expression of hsp70 gene and the bioassays at individual level were combined to investigate the responses of $F$. candida to soil $\mathrm{Hg}$ pollution in this study, which provided more integrated information to evaluate its toxicity and ecological risk from individual to molecular levels. The results of comparison between the different endpoints indicated that expression of the hsp70 gene was the most sensitive in the toxicological bioassays according to their EC50 values; i.e., the hsp70 gene expression had the lowest EC50 value. In addition, the LOEC value of hsp70 gene expression was $0.25 \mathrm{mg} / \mathrm{kg}$, which was much lower than LOEC values according to the tests of reproduction and avoidance. Therefore, the hsp 70 gene of $F$. candida should be a more promising biomarker of soil $\mathrm{Hg}$ pollution.

The present study provides initial evidence that tests of avoidance and the hsp70 biomarker of the springtail $F$. candida exhibited more sensitive responses to soil $\mathrm{Hg}$ stress than reproduction and, moreover, than mortality. The sensitivity of avoidance behavior indicated that the test could be regarded as a fast and sensitive tool in the screening evaluation of soil contamination, which would rapidly yield information for future decisions on the evaluation procedure. Although the results of the reproduction test using $F$. candida were comparable to Eisenia fetida and Enchytraeus albidus reproduction test results [20], the test was not considered to be a promising method for evaluating polluted soils, because it is time consuming. In particular, the biomarker of hsp70 provided an optional means of quantifying environmental harm when a low concentration of pollutant was present. Thus, environmental monitoring using this hsp70 gene expression in F. candida might be helpful in the early diagnosis of potentially polluted sites.

Acknowledgement-This work was supported by the Ministry of Sciences and Technology (863 Program, 2009AA06Z402), the Chinese Academy of Sciences (kzcx1-yw-06-03), and the National Scientific Foundation of China (40671172). Y.R. Liu and Y.M. Zheng contributed equally to this work.

\section{REFERENCES}

1. Nriagu JO, Pacyna JM. 1988. Quantitative assessment of worldwide contamination of air, water, and soils by trace-metals. Nature 333:134139.

2. Son J, Ryoo MI, Jung J, Cho K. 2007. Effects of cadmium, mercury and lead on the survival and instantaneous rate of increase of Paronychiurus kimi (Lee) (Collembola). Appl Soil Ecol 35:404-411.

3. Lock K, Janssen CR. 2001. Ecotoxicity of mercury to Eisenia fetida, Enchytraeus albidus, and Folsomia candida. Biol Fertil Soils 34:219221.

4. Fountain MT, Hopkin SP. 2005. Folsomia candida (Collembola): a "standard", soil arthropod. Annu Rev Entomol 50:201-222.

5. Criel P, Lock K, Van Eeckhout H, Oorts K, Smolders E, Janssen CR. 2008. Influence of soil properties on copper toxicity for two soil invertebrates. Environ Toxicol Chem 27:1748-1755.

6. Crouau Y, Pinelli E. 2008. Comparative ecotoxicity of three polluted industrial soils for the Collembola Folsomia candida. Ecotoxicol Environ Saf 71:643-649.

7. Dawson JJC, Godsiffe EJ, Thompson IP, Ralebitso-Senior TK, Killham KS, Paton GI. 2007. Application of biological indicators to assess recovery of hydrocarbon impacted soils. Soil Biol Biochem 39:164-177.

8. Fernandez MD, Cagigal E, Vega MM, Urzelai A, Babin M, Pro J, Tarazona JV. 2005. Ecological risk assessment of contaminated soils through direct toxicity assessment. Ecotoxicol Environ Saf 62:174-184.

9. Jager T, Crommentuijn T, van Gestel CAM, Kooijman SALM. 2007. Chronic exposure to chlorpyrifos reveals two modes of action in the springtail Folsomia candida. Environ Pollut 145:452-458. 
10. Menta C, Maggiani A, Vattuone Z. 2006. Effects of $\mathrm{Cd}$ and $\mathrm{Pb}$ on the survival and juvenile production of Sinellacoeca and Folsomia candida. Eur J Soil Biol 42:181-189.

11. Scott-Fordsmand JJ, Krogh PH, Weeks JM. 2000. Responses of Folsomia candida (Collembola: Isotomidae) to copper under different soil copper concentration histories in relation to risk assessment. Environ Toxicol Chem 19:1297-1303.

12. da Luz TN, Ribeiro R, Sousa JP. 2004. Avoidance tests with Collembola and earthworms as early screening tools for site-specific assessment of polluted soils. Environ Toxicol Chem 23:2188-2193.

13. Natal-da-Luz T, Amorim MJB, Rombke J, Sousa JP. 2008. Avoidance tests with earthworms and springtails: defining the minimum exposure time to observe a significant response. Ecotoxicol Environ Saf 71:545551 .

14. Martinez Aldaya M, Lors C, Salmon S, Ponge JF. 2006. Avoidance bioassays may help to test the ecological significance of soil pollution. Environ Pollut 140:173-180.

15. Spurgeon DJ, Sturzenbaum SR, Svendsen C, Hankard PK, Morgan AJ, Weeks JM, Kille P. 2004. Toxicological, cellular and gene expression responses in earthworms exposed to copper and cadmium. Comp Biochem Physiol C 138:11-21.

16. Roelofs D, Aarts MGM, Schat H, van Straalen NM. 2008. Functional ecological genomics to demonstrate general and specific responses to abiotic stress. Funct Ecol 22:8-18.

17. Timmermans MJ, de Boer ME, Nota B, de Boer TE, Marien J, KleinLankhorst RM, van Straalen NM, Roelofs D. 2007. Collembase: a repository for springtail genomics and soil quality assessment. $B M C$ Genomics 8:341-350.

18. Nota B, Bosse M, YlstraB, van Straalen NM, Roelofs D. 2009. Transcriptomics reveals extensive inducible biotransformation in the soil-dwelling invertebrate Folsomia candida exposed to phenanthrene. BMC Genomics 10:236-248.

19. Nota B, Timmermans MJ, Franken O, Montagne-Wajer K, Mariën J, de Boer ME, de Boer TE, Ylstra B, van Straalen NM, Roelofs D. 2008. Gene expression analysis of Collembola in cadmium containing soil. Environ Sci Technol 42:8152-8157.

20. Kammenga JE, Dallinger R, Donker MH, Kohler HR, Simonsen V, Triebskorn R, Weeks JM. 2000. Biomarkers in terrestrial invertebrates for ecotoxicological soil risk assessment. Rev Environ Contam Toxicol 164:93-147.

21. Morgan AJ, Kille P, Sturzenbaum SR. 2007. Microevolution and ecotoxicology of metals in invertebrates. Environ Sci Technol 41:10851096.

22. Arts M-JSJ, Schill RO, Knigge T, Eckwert H, Kammenga JE, Köhler H-R. 2004. Stress proteins (hsp70, hsp60) induced in isopods and nematodes by field exposure to metals in a gradient near Avonmouth, UK. Ecotoxicology 13:739-755.

23. Brulle F, Mitta G, Cocquerelle C, Vieau D, Lemiere S, Lepretre A, van den Bulcke F. 2006. Cloning and real-time PCR testing of 14 potential biomarkers in Eisenia fetida following cadmium exposure. Environ Sci Technol 40:2844-2850.

24. Lewis S, Handy RD, CordiB, Billinghurst Z, Depledge MH. 1999. Stress proteins (HSPs): methods ofdetection and their use as an environmental biomarker. Ecotoxicology 8:351-368.

25. Feder ME, Hofmann GE. 1999. Heat-shock proteins, molecular chaperones, and the stress response: evolutionary and ecological physiology. Annu Rev Physiol 61:243-282.
26. Sorensen JG, Kristensen TN, Loeschcke V. 2003. The evolutionary and ecological role of heat shock proteins. Ecol Lett 6:1025-1037.

27. Sorger PK. 1991. Heat-shock factor and the heat-shock response. Cell 65:363-366

28. Homa J, Olchawa E, Sturzenbaum SR, Morgan AJ, Plytycz B. 2005. Early-phase immunodetection of metallothionein and heat shock proteins in extruded earthworm coelomocytes after dermal exposure to metal ions. Environ Pollut 135:275-280.

29. Nadeau D, Corneau S, Plante I, Morrow G, Tanguay RM. 2001. Evaluation for Hsp70 as a biomarker of effect of pollutants on the earthworm Lumbricus terrestris. Cell Stress Chaperones 6:153-163.

30. Bahrndorff S, Maien J, Loeschcke V, Ellers J. 2009. Dynamics of heatinduced thermal stress resistance and Hsp70 expression in the springtail, Orchesella cincta. Funct Ecol 23:233-239.

31. Holmstrup M, Aubail A, Damgaard C. 2008. Exposure to mercury reduces cold tolerance in the springtail Folsomia candida. Comp Biochem Physiol C 148:172-177.

32. Slotsbo S, Heckmann LH, Damgaard C, Roelofs D, de Boer T, Holmstrup M. 2009. Exposure to mercury reduces heat tolerance and heat hardening ability of the springtail Folsomia candida. Comp Biochem Physiol C 150:118-123

33. Walkley A, Black IA. 1934. An examination of the Degtjareff method for determining soil organic matter, and a proposed modification of the chromic acid titration method. Soil Sci 37:29-38.

34. Zheng YM, Liu YR, Hu HQ, He JZ. 2008. Mercury in soils of three agricultural experimental stations with long-term fertilization in China Chemosphere 72:1274-1278.

35. International Organization for Standardization. 1999. Soil qualityinhibition of reproduction of Collembola (Folsomia candida) by soil pollutants. ISO 11267. Geneva, Switzerland.

36. Van Ewijk PH, Hoekstra JA. 1993. Calculation of the EC50 and its confidence interval when subtoxic stimulus is present. Ecotoxicol Environ Saf 25:25-32.

37. Stephenson GL, Koper N, Atkinson GF, Solomon KR, Scroggins RP. 2000. Use of nonlinear regression techniques for describing concentration-response relationships of plant species exposed to contaminated site soils. Environ Toxicol Chem 19:2968-2981.

38. Crouau Y, Chenon P, Gisclard C. 1999. The use of Folsomia candida (Collembola, Isotomidae) for the bioassay of xenobiotic substances and soil pollutants. Appl Soil Ecol 12:103-111.

39. Lock K, Becaus S, Criel P, Van Eeckhout H, Janssen CR. 2004 Ecotoxicity of cobalt to the springtail Folsomia candida. Comp Biochem Physiol C 139:195-199.

40. Loureiro S, Soares A, Nogueira AJA. 2005. Terrestrial avoidance behaviour tests as screening tool to assess soil contamination. Environ Pollut 138:121-131.

41. Lors C, Martinez Aldaya M, Salmon S, Ponge JF. 2006. Use of an avoidance test for the assessment of microbial degradation of PAHs. Soil Biol Biochem 38:2199-2204.

42. Brulle F, Mitta G, Leroux R, Lemiere S, Lepretre A, Vandenbulcke F. 2007. The strong induction of metallothionein gene following cadmium exposure transiently affects the expression of many genes in Eisenia fetida: a trade-off mechanism? Comp Biochem Physiol C 144:334-341.

43. Tully T, d'Haese CA, Richard M, Ferriere R. 2006. Two major evolutionary lineages revealed by molecular phylogeny in the parthenogenetic Collembola species Folsomia candida. Pedobiologia 50:95-104. 